\title{
Airport Internships: Effectively Structuring a Departmental Rotation Internship
}

\author{
C. Daniel Prather \\ Tampa, Florida
}

\begin{abstract}
Author Note
This study on the perceptions of airport managers regarding airport internships is one aspect of a paper entitled Airport internships: Combining formal education and practical experience for a successful airport management career, which was prepared as a requirement for the American Association of Airport Executives' (AAAE) Accreditation program. The remaining aspect of the AAAE paper, which was published in the 1998 Collegiate Aviation Review, is a study on the views of airport managers regarding postsecondary aviation education. Findings presented do not necessarily reflect the views of my employer, the Hillsborough County Aviation Authority.
\end{abstract}

\begin{abstract}
Preparing for a career in airport management not only requires appropriate education, but formal training as well. Too often, many college graduates are faced with no experience and entry-level airport management positions that require some experience. Unless a recent graduate is able to secure an airport internship, progression in the airport management field may seem daunting, if not impossible. To this end, this article presents findings on the expert opinions of airport managers nationwide regarding the most important airport departments in which an intern should gain experience, the benefits of internship programs, and the recommended structure of a departmental rotation airport internship program. Utilizing the 1996-97 AAAE Membership Directory and Yellow Pages of Corporate Members (American Association of Airport Executives, 1997), a written mail survey was sent to a nationwide random sample of 200 airport managers in January 1998. Results, which are presented using percentage distribution tables and descriptive statistics, show that the majority of airport managers view their careers as challenging and interesting, consider Finance along with Planning \& Development the most important airport departments in which an intern should gain experience, and feel that an internship program is extremely beneficial to the intern, while also being beneficial to the airport.
\end{abstract}




\section{INTRODUCTION}

On-the-job training was once sufficient for the individual entering the field of airport management. In one sense, it still is. Today, however, this formal training program is known as airport internships. Individuals no longer may be able to enter the field with sufficient education alone. Experience is now a necessity and for those recently graduated, this experience may seem impossible to obtain. Airports offering internships are allowing individuals new to the field to apply knowledge gained in the classroom to practical airport business.

An article by Thiessee, NewMyer, and Widick (1992) details five traditional structures of an airport intern program. The first alternative is known as job shadowing. The intern becomes an administrative assistant to the airport manager, thereby learning by close managerial cooperation. Second, a departmental rotation internship allows the intern to rotate through the various departments at the airport, such as public relations, ground transportation, operations, and maintenance. At smaller airports without these separate departments, the job-shadowing role becomes more prevalent. The third alternative is a single department-based internship, which allows the student to gain experience in only one department. Although this is not advisable for airport management students, it is common for mechanical engineering students to intern solely in one area, such as the Facilities department at an airport. The academic internship seeks as its end goal a report, presentation, manual, or brochure/booklet. This arrangement begins with a short period of job shadowing, quickly followed by intense research on the task at hand. Finally, a specific task internship may be similar to the academic internship, but is designed to give interns experience that is task-oriented, not necessarily departmentally based.

The author conducted research to determine which of these five types of internships is most prevalent in the airport industry. Since the "Positions Open" section of AAAE's Airport Report appears to be the authoritative nationwide source of available airport internships, each issue of this newsletter was examined during the October 1992 through October 1997 time period. These 120 issues yielded 27 internship advertisements for a total of 35 available internship positions.

During these five years and of these 35 positions, 40 percent (14) had a title of Airport Management Intern, 34 percent (12) were recognized as Airport Interns, and 9 percent (3) were Administrative Interns. The majority of the appointments (51 percent) were for a term of two years. Nine percent advertised a 15-week (summer) training program. Other lengths were one year along with six months. Finally, 94 percent (33) were rotational in structure, explained by Theisse et al. (1992) as a departmental rotation internship. Due to the ubiquity of departmental rotation internships at airports offering internships, this paper focuses specifically on this arrangement. Appendix A is a listing, by airport, of the internship positions that were advertised during this time period.

The airport business is in a constant state of dynamics and as airport managers are responding to this change, so too should recent graduates. For this to be effectively accomplished, current airport managers, those aspiring to become such, and universities assisting with this task, should be aware of the perceptions of airport managers regarding four important areas: (a) descriptive words applicable to the airport management career, (b) the relative importance of airport departments in which 
to gain experience, (c) the benefits of airport internship programs, and (d) the recommended number of work days an airport intern should spend in each airport department.

As such, this paper details the findings of a survey sent to 200 randomly selected airport managers in a nationwide study. Their opinions on their airport management career, the relative importance of different airport departments in which an intern should gain experience, and the benefits of airport internship programs were sought. These responses allowed the author to devise formulae that may be adopted by airports to appropriately structure a departmental rotation internship at their airport. It is hoped that data presented and recommendations made will assist airport managers, recent graduates, and university aviation programs in becoming properly educated about the needs of the airport manager of tomorrow.

Methodology

\section{Participants}

In selecting participants for this study, the 1996-97 AAAE Membership Directory and Yellow Pages of Corporate Members (AAAE, 1997) was utilized. This directory contains a comprehensive listing of airport managers nationwide. Indeed, AAAE's membership is comprised of airport managers employed at the primary air carrier airports, accounting for 99 percent of nationwide enplanements, as well as at many of the smaller commercial service, reliever, and general aviation airports. Each individual member airport was counted to arrive at a total population of 690 airports. Out of this total, the goal was to receive 150 (n) usable surveys; therefore, assuming a response rate of 75 percent $(\mathrm{p})$, the selected sample size was $200(\mathrm{~N})[\mathrm{n} / \mathrm{p}=\mathrm{N}]$. Each airport in the Directory was numbered alphabetically and a random numbers table
[Table B-1 in the text by Alreck and Settle (1995)] was used to arrive at 200 randomly selected numbers. These numbers were then matched to the corresponding airports to arrive at a random sample of 200 airports to use for the study. This random sampling methodology was chosen for two reasons. First, it avoids the possibility of bias introduced by a nonrandom selection of sample elements. Second, it provides a probabilistic basis for the selection of a sample.

\section{Survey Instrument}

Since viewpoints were the main end product desired in this study, it was decided that a survey instrument would be utilized. Surveys can be designed to "measure things as simple as respondents' physical or demographic characteristics or as complex as their attitudes, preferences, or lifestyle patterns" (Alreck and Settle, 1995, p. 5). Further, because survey research uses sampling, information about an extremely large population can be obtained from a relatively small sample of people. As a result, the author designed a four-page survey instrument specifically for this study (see Appendix B). All questions were closed-ended to allow for easier coding of data. Further, many questions were scaled on a five point Likert scale. This was used to "obtain people's position on certain issues or conclusions" (Alreck \& Settle, 1995, p. 116).

The survey begins with a definition of Airport Manager, which is defined as "the individual managing all facets of the day-today activities of the airport and known by such titles as Executive Director and Director of Aviation." Airport Intern is defined as "an individual working full- or part-time in a temporary status gaining experience in the airport management field." These definitions, which are defined by the author, were included to reduce any 
misunderstanding that might arise when these terms were encountered while completing the survey. The survey then progresses into Section A, which is composed of an adjective checklist. This section allowed some exploratory research into how airport managers view their career. This type of question was included for the benefit of current students who may be interested in knowing the percentage of survey respondents considering the career stressful or political, for example.

The next section focused on the departments at an airport to which an intern might be exposed. The section was scaled on a Likert scale to allow for responses of airport managers to be gauged on this fivepoint scale. Choices included 0 (Don't Know), 1 (Extremely Unimportant), 2 (Unimportant), 3 (Neutral), 4 (Important), and 5 (Extremely Important). Participants were instructed to circle the number that most closely corresponded to their opinion about the importance of each airport department.

The section focusing on airport departments presented fifteen airport departments, listed in alphabetical order. The actual departments, ranging from Aircraft Rescue and Fire Fighting to Records Management, are most common to medium and large hub airports. The functions represented, however, are common to airports of any size.

Participants were also instructed to register their opinion regarding the benefits of airport internship programs in general. This section also consisted of a Likert scale with choices composed of 0 (Don't Know), 1 (Extremely Unimportant), 2 (Unimportant), 3 (Neutral), 4 (Important), and 5 (Extremely Important).

\section{Procedure}

In the cover letter accompanying each survey, participants were instructed on the reason for the research, how they were chosen, the importance of their participation, the estimated time required to complete the survey, and the fact that participation was voluntary. Further, they were told to skip any questions they did not want to answer. As discussed earlier, the sample chosen was a simplified random sample without replacement, in that each participant had an equal probability of being selected, and once selected, would not be chosen again.

The section focusing on descriptive words stated, "Which of the following words describe your airport management career?" Participants were instructed to place a check next to any and all words that applied. Regarding airport departments, participants were asked, "For a successful career as an airport manager, how important do you feel practical experience is in each of the following airport departments?" Participants were instructed to circle the number corresponding to their feeling of department importance for each item. Finally, regarding the importance of internship programs, participants were asked, "In general, how beneficial do you feel an airport internship program is to the intern and the airport?" As with the previous section, participants were given a Likert scale and asked to circle the number most closely corresponding to their feeling of each item.

The 200 surveys were mailed on December 30, 1997. As of January 12, 1998, a response rate of 43 percent (86 surveys) had been received. Following the advice of Fowler (1993), a reminder postcard to all non-respondents was mailed emphasizing the importance of the study and the benefit of a high rate of response. One hundred and three postcards were mailed to all nonrespondents on January 15, 1998. This reminder mailing gave recipients the opportunity to receive another survey by fax, but only one recipient made such a 
request. This second mailing resulted in a total survey response rate of 66 percent, with 132 usable surveys being returned by the established deadline.

\section{Data Analysis}

Once the surveys were returned, a statistical analysis program, SPSS for Windows, was utilized to analyze the survey results. Descriptive statistics were produced, including frequencies, means, and standard deviations. The results are reproduced in this article in a tabular format to allow for easy comparison among categories.

\section{RESULTS}

\section{Demographics}

As a result of the 34 percent (68) of survey recipients who did not respond, one may ask if this introduced non-response bias into the results. The respondents of this survey very closely match the AAAE membership at large. This membership, according to AAAE, is "truly representative of airport management throughout the country" (AAAE, 1998). AAAE membership is composed of non-hub, other commercial service, and general aviation airports $(75 \%)$, large hub (5\%), medium hub $(8 \%)$, and small hub (12\%) (Susan Lausch, AAAE, personal fax, February 20, 1998). The survey respondents were composed of non-hub, other commercial service, and general aviation (72\%), large hub (7\%), medium hub (9\%), and small hub (13\%). Therefore, due to the random nature of the design and the apparent random nature of responses, these survey results should prove statistically significant and may be generalized to the population of airport managers nationwide.

The respondents were 88 percent male and 12 percent female. Thirty-nine percent of participants were more than 50 years of age, with 34 percent and 23 percent being between 41 and 50 years of age and 30 to 40 years of age, respectively. Further, 45 percent of respondents are known as Airport Managers, with 20 percent being known as Airport Directors. It should be noted that although most airport managers are male, the number of females obtaining this position seems to be on the increase. In fact, according to a study in 1994 by Truitt, Hamman, and Palinkas, 94 percent of responding airport managers were males. Therefore, it appears that females are recognizing the opportunities in airport management and contributing to the diversity of this profession.

\section{Descriptive Words}

The first section of the survey listed 15 adjectives to allow airport managers to describe their airport management career. This exploratory research will prove helpful to students who are aspiring to enter the airport industry. Further, it gives current airport managers insight into how their peers view the career. Table 1 is a tabular display of those words and the numbers and percentages of respondents agreeing with each. 
Table 1

Evaluation of Words Describing Airport Management Career

\begin{tabular}{|l|r|r|}
\hline & \multicolumn{1}{|c|}{ Yes } & \multicolumn{1}{c|}{ No } \\
\hline Challenging & $118(90)$ & $13(10)$ \\
\hline Competitive & $53(41)$ & $78(60)$ \\
\hline Dangerous & $6(05)$ & $125(95)$ \\
\hline Disappointing & $12(09)$ & $119(91)$ \\
\hline Easy & $6(05)$ & $125(95)$ \\
\hline Enjoyable & $89(68)$ & $42(32)$ \\
\hline Exciting & $76(58)$ & $55(42)$ \\
\hline Fulfilling & $72(55)$ & $59(45)$ \\
\hline Important & $88(67)$ & $43(33)$ \\
\hline Interesting & $119(91)$ & $12(09)$ \\
\hline Low-Paying & $23(18)$ & $108(82)$ \\
\hline Political & $91(70)$ & $40(31)$ \\
\hline Rewarding & $90(69)$ & $41(31)$ \\
\hline Secure & $18(14)$ & $113(86)$ \\
\hline Stressful & $83(63)$ & $48(37)$ \\
\hline
\end{tabular}

Note 1: Number in parentheses represents percentages.

Note 2: Row percentages may not total 100 percent due to rounding.

Note 3: Words are listed in alphabetical order as they appeared on survey instrument. Note 4: $\mathrm{N}=131$ for all cases.

Ninety-one percent of respondents feel their career is interesting and ninety percent feel it is challenging. These two words claimed the majority of positive responses; however, the following words were also identified by respondents as describing their airport management career: political (70\%), rewarding $(69 \%)$, enjoyable (68\%), important (67\%), stressful (63\%), exciting (58\%), and fulfilling (55\%). Words receiving very little agreement are dangerous (5\%) and easy (5\%). Therefore, for those aspiring to be airport managers and wishing for an interesting and challenging career, the field of airport management would appear to be a reasonable choice. These students should also realize, however, that the field is political, stressful, and not very easy, according to the survey results.

\section{Table 2}

Evaluation of Words Describing Airport Management Career Ranking of Mean Ratings

\begin{tabular}{|l|c|c|}
\hline Words & M & SD \\
\hline Interesting & 1.092 & 0.290 \\
\hline Challenging & 1.099 & 0.300 \\
\hline Political & 1.305 & 0.462 \\
\hline Rewarding & 1.313 & 0.465 \\
\hline Enjoyable & 1.321 & 0.469 \\
\hline Important & 1.328 & 0.471 \\
\hline Stressful & 1.366 & 0.484 \\
\hline Exciting & 1.420 & 0.495 \\
\hline Fulfilling & 1.450 & 0.499 \\
\hline Competitive & 1.595 & 0.493 \\
\hline Low-paying & 1.824 & 0.382 \\
\hline Secure & 1.863 & 0.346 \\
\hline Disappointing & 1.908 & 0.290 \\
\hline Dangerous & 1.954 & 0.210 \\
\hline Easy & 1.954 & 0.210 \\
\hline
\end{tabular}

Note 1: Rating system utilized as follows:

$$
\begin{aligned}
& 1=\text { Yes (Agreed) } \\
& 2=\text { No (Disagreed) }
\end{aligned}
$$

Note 2: Words are listed by ascending value of mean.

Note 3: $\mathrm{M}=$ Mean; $\mathrm{SD}=$ standard deviation

Table 2 is a listing of the descriptive statistics related to each word. Words are listed in ascending order by value of Mean. In other words, the lowest value Mean equates to the highest level of agreement. These data simply confirm the findings presented in the percentage distribution table (Table 1). 


\section{Airport Departments}

In examining the importance of airport departments, the goal is to arrive at the most appropriate structure of a departmental rotation internship program. Specifically, which airport departments should the intern experience and how much time should be spent in each department? The answers to these questions will obviously vary with each airport as staffing and time allow. Nonetheless, it is informative to know those departments which are seen as important by airport managers, so those airports interested in providing departmental rotation internships may structure their program accordingly. Further, this information gives students insight into which departments are most important as they begin seeking practical experience within the airport industry. (Please refer to Tables 3 and 4.)
Combining the important and extremely important categories, Finance accompanied by Planning and Development tied for first place, each receiving 92 percent of responses in these two categories. Other departments viewed as important and extremely important were Properties and Contracts (89\%), Operations (88\%), Information/Public Relations (83\%), General Aviation (76\%), Facilities/ Maintenance (72\%), Design and Construction (69\%), and Human Resources $(65 \%)$. At the other extreme, two departments which received the most marks for extremely unimportant and unimportant are International Commerce (34\%) and Aircraft Rescue/Fire Fighting (27\%). Airport managers feel these last two departments should not receive much emphasis in an internship program. 
Table 3

Evaluation of Airport Departments

\begin{tabular}{|c|c|c|c|c|c|c|}
\hline & $\begin{array}{c}\text { Extremely } \\
\text { Un- } \\
\text { Important }\end{array}$ & $\begin{array}{c}\text { Un- } \\
\text { Important }\end{array}$ & Neutral & Important & $\begin{array}{l}\text { Extremely } \\
\text { Important }\end{array}$ & \\
\hline Airport Departments & 1 & 2 & 3 & 4 & 5 & $n$ \\
\hline $\begin{array}{l}\text { Aircraft Rescue/Fire } \\
\text { Fighting }\end{array}$ & $10(08)$ & $24(19)$ & $32(25)$ & $42(32)$ & $22(17)$ & 130 \\
\hline Records Management & $6(05)$ & $19(15)$ & $42(33)$ & $45(35)$ & $17(13)$ & 129 \\
\hline Design and Construction & $1(01)$ & $9(07)$ & $31(24)$ & $68(53)$ & $20(16)$ & 129 \\
\hline Communications Center & $6(05)$ & $20(16)$ & $55(43)$ & $38(30)$ & $9(07)$ & 128 \\
\hline Facilities/Maintenance & $1(01)$ & $3(02)$ & $32(24)$ & $70(53)$ & $25(19)$ & 131 \\
\hline Finance & $1(01)$ & $1(01)$ & $9(07)$ & $61(47)$ & $59(45)$ & 131 \\
\hline General Aviation & 0 & $8(06)$ & $23(18)$ & $71(54)$ & $29(22)$ & 131 \\
\hline Ground Transportation & $2(02)$ & $25(19)$ & $53(41)$ & $45(35)$ & $5(04)$ & 130 \\
\hline Human Resources & 0 & $5(04)$ & $39(31)$ & $53(42)$ & $29(23)$ & 126 \\
\hline $\begin{array}{l}\text { Information/Public } \\
\text { Relations }\end{array}$ & $1(01)$ & $2(02)$ & $20(16)$ & $57(45)$ & $48(38)$ & 128 \\
\hline International Commerce & $12(11)$ & $26(23)$ & $52(46)$ & $20(18)$ & $3(03)$ & 113 \\
\hline Operations & $1(01)$ & $2(02)$ & $13(10)$ & $60(46)$ & $54(42)$ & 130 \\
\hline Planning and Development & 0 & $1(01)$ & $10(08)$ & $70(54)$ & $49(38)$ & 130 \\
\hline Police/Security & $5(04)$ & $18(14)$ & $48(37)$ & $48(37)$ & $10(08)$ & 129 \\
\hline Properties and Contracts & 0 & $4(03)$ & $11(08)$ & $73(56)$ & $43(33)$ & 131 \\
\hline
\end{tabular}

Note 1: Number in parentheses represents percentages

Note 2: Row percentages may not total 100 percent due to rounding

Note 3: $n$ reflects all valid cases, excepting “Don't Know” responses and nonresponses 


\section{Table 4}

Evaluation of Airport Departments

Ranking of Mean Ratings

\begin{tabular}{|l|c|c|}
\hline Departments & M & SD \\
\hline International Commerce & 2.788 & 0.949 \\
\hline Communications Center & 3.187 & 0.945 \\
\hline Ground Transportation & 3.200 & 0.848 \\
\hline Police/Security & 3.310 & 0.942 \\
\hline Aircraft Rescue/Fire Fighting & 3.323 & 1.183 \\
\hline Records Management & 3.372 & 1.039 \\
\hline Design and Construction & 3.752 & 0.829 \\
\hline Human Resources & 3.841 & 0.824 \\
\hline Facilities/Maintenance & 3.878 & 0.765 \\
\hline General Aviation & 3.924 & 0.800 \\
\hline Information/Public Relations & 4.164 & 0.801 \\
\hline Properties and Contracts & 4.183 & 0.710 \\
\hline Operations & 4.262 & 0.763 \\
\hline Planning and Development & 4.285 & 0.638 \\
\hline Finance & 4.344 & 0.710 \\
\hline Note 1: Rating system provided for
\end{tabular}

Note 1: Rating system provided for evaluators was as follows:

$$
\begin{aligned}
& 0=\text { Don't Know } \\
& 1=\text { Extremely Unimportant } \\
& 2=\text { Unimportant } \\
& 3=\text { Neutral } \\
& 4=\text { Important } \\
& 5=\text { Extremely Important }
\end{aligned}
$$

Note 2: Only responses 1-5 were used in calculating statistics.

Note 3: $\mathrm{M}=$ mean; $\mathrm{SD}=$ standard deviation 
In using these numbers to most efficiently structure a departmental rotation internship program, one must keep in mind that these data represent expert opinion of airport managers only. They do not take into account the views of interns who may wish to learn more about Aircraft Rescue/Fire Fighting, for example, even though it is considered of little importance to airport managers.

\section{INTERNSHIP PROGRAM BENEFITS}

For those airports and students still doubting the value of internships, it may prove helpful to analyze the extent of benefits, as stated by airport managers, of airport internships in general to both the airport and intern involved. These responses, therefore, do not necessarily focus solely on departmental rotation internships. It will first be insightful to examine the number of survey participants who have actually experienced an internship. Eighty-seven percent of respondents have never been employed as an airport intern. Of the 13 percent of respondents who have, only 5 individuals report this being a requirement for graduation. Furthermore, 53 percent of responding airports do not have an active internship program. Of those, 69 percent state they would not be willing and able to implement an internship program under sufficient guidance. Although the specific reasoning for this finding was not addressed in the survey, written comments indicated that lack of funding is a hindrance in implementing an internship program at some responding airports. However, eighteen airports are willing and able to implement such a program and five airports responded with maybe. As such, it is prudent to discuss the benefits associated with implementing an internship program.

Table 5

Evaluation of Airport Internship Program Benefits

\begin{tabular}{|l|c|c|c|c|c|c|}
\cline { 2 - 7 } \multicolumn{1}{c|}{} & $\begin{array}{c}\text { Extremely } \\
\text { non- } \\
\text { Beneficial }\end{array}$ & $\begin{array}{c}\text { Non- } \\
\text { Beneficial }\end{array}$ & Neutral & Beneficial & $\begin{array}{c}\text { Extremely } \\
\text { Beneficial }\end{array}$ & \\
\hline Beneficiary & $\mathbf{1}$ & $\mathbf{2}$ & $\mathbf{3}$ & $\mathbf{4}$ & $\mathbf{5}$ & $\boldsymbol{n}$ \\
\hline Intern & 1 & 0 & 8 & 34 & 73 & 116 \\
& $(01)$ & & $(07)$ & $(29)$ & $(63)$ & \\
\hline Airport & 1 & 5 & 36 & 41 & 18 & 101 \\
& $(01)$ & $(05)$ & $(36)$ & $(41)$ & $(18)$ & \\
\hline
\end{tabular}

Note 1: Number in parentheses represents percentages.

$\underline{\text { Note } 2: ~} n$ reflects all valid cases

Sixty-three percent of respondents feel that an internship program is extremely beneficial to the intern, with 29 percent feeling it is beneficial to the intern. Benefits lessen but are still quite high with regard to airports. Fifty-nine percent of respondents feel internships are a combination of extremely beneficial and beneficial to airports. Thirty-six percent of participants are neutral on this subject. It is obvious, therefore, that benefits exist to a high degree for both interns and the airports employing them (Tables 5 and 6). 
Table 6

Evaluation of Airport Internship Program Benefits Ranking of Mean Ratings

\begin{tabular}{|l|c|c|}
\hline Beneficiary & M & SD \\
\hline Intern & 4.661 & 0.789 \\
\hline Airport & 4.025 & 1.136 \\
\hline
\end{tabular}

Note 1: Rating system provided for evaluators was as follows:

$$
\begin{aligned}
& 0=\text { Don't Know } \\
& 1=\text { Extremely Nonbeneficial } \\
& 2=\text { Nonbeneficial } \\
& 3=\text { Neutral } \\
& 4=\text { Beneficial } \\
& 5=\text { Extremely Beneficial }
\end{aligned}
$$

Note 2: Only responses 1-5 were used in calculating statistics.

Note $3: \mathrm{M}=$ mean; $\mathrm{SD}=$ standard deviation

\section{Recommended Structure of Departmental Rotation Airport Internship Program}

As stated earlier, one of the purposes of this essay is to recommend to airport managers the most appropriate structure of a departmental rotation airport internship program. This section outlines the recommended structure for internship programs lasting two years, one and onehalf years, and one year.

The procedure in structuring an internship program should occur in the following steps: (a) rank the departments at your airport using tables 3 and 4, (b) determine the amount of total time the intern will work at your airport, (c) use the formula outlined below to determine the number of days the intern should spend in each airport department.

The formulae, which were designed by the author as a result of this research effort, produce the number of days in which an intern should spend in each department according to the level of importance each department received in the survey. These formulae are guidelines only; however, the number of days suggested by the formulae correlate to the perceived importance of each department and are quite reasonable as a timeframe for each intern. If the intern program is for two years, the following formula should be used: $0.5(a+b)=y$ days. The first variable, $a$, is the percentage of important marks for that department, without the percent sign. Next, $b$ is the percentage of extremely important marks for that department, without the percent sign. Finally, $y$ is the actual number of workdays the intern should spend in that department on a continuous basis. If the intern program is for a length of one and one-half years, the following formula is suggested: $0.4(a+b)$ $=y$ days. If the intern program is to last one year, use the following:

$0.3(a+b)=y$ days.

The formulae are designed to give the airport manager a rough rule-of-thumb to use in determining the length of time an intern should spend in each airport department. The reader must remember that the numbers generated by the formulae yield the actual number of workdays suggested. Fourteen days, for instance, equates to almost three calendar weeks, rather than two calendar weeks. The total numbers are based on a standard of 260 workdays per year. This equates to 21.6 working days per month. Therefore, if a formula yields 21.6 for a department, the airport manager should assign the intern to that department for an entire calendar month.

These formulae assume (a) that there is no "home" department to which the intern must return after each departmental rotation, (b) that time spent in each department is continuous, and (c) that a minimum of one workweek (five days) is spent in each department regardless of the level of perceived importance or equation result. For the actual amount of suggested time that should be spent in each department, 
depending on whether the internship is two years, one and one-half years, or one year, refer to Appendix C.

\section{Extent of Experience Necessary}

For those students aspiring to become airport managers, it will prove helpful to examine how airport managers feel regarding the number of years experience required to obtain such a position. Of those working at large hub airports, 66 percent state that 10 to 15 years of experience are needed to obtain a position of airport manager at a large hub airport. Of those working at a medium hub, 73 percent report that 10 to 15 years are needed to obtain a position of airport manager at a medium hub airport. Small hub respondents $(71 \%)$ consider 15 years or less are necessary at a small hub airport. Non-hub respondents $(97 \%)$ report that 15 years or less are necessary at a non-hub airport. Other commercial service respondents $(92 \%)$ explain that less than 10 years is adequate at these airports. Finally, 98 percent of general aviation respondents report that less than fifteen years of experience are necessary to obtain a position of airport manager at a GA airport.

Fortunately, according to these numbers, airport management neophytes can reasonably expect to become an airport manager at a large hub airport by the age of 36. Assuming entry into the industry at the age of 21, probabilities increase that one will obtain a position of airport manager by the age of 36 as hubs decrease in size. In other words, it is much more feasible to obtain a position of airport manager at a general aviation airport by the age of 36 than a large hub. Even so, these numbers serve to motivate young individuals in the field who have such high aspirations.

\section{Recommendations}

The main purpose of this research is to offer recommendations regarding departmental rotation airport internships to aviation management students, universities, and airport managers. These recommendations will hopefully assist these parties in responding to the complex challenges that are to be expected in the next century.

\section{Aviation management students}

1. Review Tables 1 and 2 to determine if an airport manager career is truly desired.

2. Review Tables 3 and 4 to understand the perceived importance by airport managers of different airport departments.

3. Review Tables 5 and 6 to realize the benefits of airport internship programs.

4. Review Appendix A for an idea of which airports have offered internship programs in the past.

\section{Universities}

1. Encourage students to search early and thoroughly for internships.

2. Build a relationship with local airports to encourage their use of interns.

3. Utilize Appendix A to inform students of airports that have offered internship programs in the past.

\section{Airport Managers}

1. Seriously consider implementing an internship program if your airport has not already done so. 
2. Study Tables 3 and 4 and Appendix $\mathrm{C}$ for guidance in appropriately structuring a departmental rotation internship program at your airport.

3. If your airport already has a nonrotational internship program in place, consider implementing a departmental rotation internship program. This type of internship is most common at airports, and appears to be most beneficial for both the airport and the students involved.

These recommendations summarize the main findings of this research. They are based mainly on the viewpoints of airport managers. Even so, these viewpoints represent current, expert opinions in the airport industry and should not be taken lightly.

\section{Conclusion}

The airport industry is currently experiencing unprecedented levels of growth. With this growth, airport managers are being forced to rely on innovative methods to obtain capital, educate employees, encourage competitive forces, and continue ensuring the safety and security of the flying public. These areas are best learned by on-the-job experience, supplemented with education. To enable airports to continue meeting the challenges that lie ahead, therefore, aspiring airport managers need to be given adequate opportunities early in their career to experience all sectors of the airport environment. Airport internships are an excellent choice in achieving this goal. 


\section{REFERENCES}

Alreck, P. L., \& Settle, R. B. (1995). The survey research handbook:

Guidelines and strategies for conducting a survey $\left(2^{\text {nd }}\right.$ ed.). Chicago: Irwin Professional Publishing.

American Association of Airport Executives. (1998). 1997-98 Membership directory and yellow pages of corporate members. Alexandria, VA: Author.

American Association of Airport Executives. (1997). 1996-97 Membership directory and yellow pages of corporate members. Alexandria, VA: Author.

American Association of Airport Executives. (October 1992 - October 1997). A Airport Report. Alexandria, VA: Author

Fowler, F. J., Jr. (1993). Survey research methods $\left(2^{\text {nd }}\right.$ ed.). Newbury Park: SAGE publications.

Thiesse, J. L., NewMyer, D. A., \& Widick, L. L. (1992). "FBO and airport internships for university aviation students: Benefits for students, universities, and the aviation industry." Journal of Studies in Technical Careers, XIV (4), 253-264.

Truitt, L. J., Hamman, J. A., \& Palinkas, K. G. (1994, Winter). Graduate education in airport administration: Preparing airport managers for the $21^{\text {st }}$ century. Journal of Aviation/Aerospace Education and Research 4 (2), 9-16. 


\section{Appendix C \\ Recommended Number of Workdays that Intern Should Spend in Each Airport Department}

\begin{tabular}{|c|c|c|c|c|c|}
\hline Airport Department & $\begin{array}{l}\text { Important } \\
(4)\end{array}$ & $\begin{array}{l}\text { Extremely } \\
\text { important (5) }\end{array}$ & \begin{tabular}{|l|} 
Time \\
allowed-
\end{tabular} & $\begin{array}{l}\text { Time } \\
\text { allowed- }\end{array}$ & \begin{tabular}{|l} 
Time \\
allowed-
\end{tabular} \\
\hline & $\mathbf{a}$ & B & \begin{tabular}{|l|} 
Two \\
Years (y) \\
\end{tabular} & $\begin{array}{l}11 / 2 \\
\text { Years (y) }\end{array}$ & 1 Year $(y)$ \\
\hline Aircraft Rescue and Firefighting & 32 & 17 & 25 & 17 & 12 \\
\hline Records Management & 35 & 13 & 24 & 15 & 12 \\
\hline Design and Construction & 53 & 16 & 35 & 20 & 16 \\
\hline Communications Center & 30 & 7 & 19 & 10 & 9 \\
\hline Facilities/Maintenance & 53 & 19 & 36 & 22 & 17 \\
\hline Finance & 47 & 45 & 46 & 36 & 25 \\
\hline General Aviation & 54 & 22 & 38 & 24 & 19 \\
\hline Ground Transportation & 35 & 4 & 20 & 9 & 9 \\
\hline Human Resources & 42 & 23 & 33 & 22 & 16 \\
\hline Information/Public Relations & 45 & 38 & 42 & 32 & 22 \\
\hline International Commerce & 18 & 3 & 11 & 5 & 5 \\
\hline Operations & 46 & 42 & 44 & 34 & 24 \\
\hline Planning and Development & 54 & 38 & 46 & 34 & 24 \\
\hline Police/Security & 37 & 8 & 23 & 12 & 10 \\
\hline Properties and Contracts & 56 & 33 & 45 & 31 & 23 \\
\hline \multicolumn{3}{|c|}{ TOTAL DAYS IN ALL DEPARTMENTS } & 483 & 324 & 242 \\
\hline \multicolumn{3}{|c|}{ TOTAL MONTHS IN ALL DEPARTMENTS } & 22 & 15 & 11 \\
\hline \multicolumn{3}{|c|}{$\begin{array}{l}\text { TOTAL MONTHS INTERN HAS } \\
\text { AVAILABLE }\end{array}$} & 24 & 18 & 12 \\
\hline \multicolumn{3}{|c|}{ NUMBER OF DAYS REMAINING AT END OF ROTATION } & 36 & 65 & 17 \\
\hline
\end{tabular}

Note 1: Formulas are as follows:

$$
\begin{array}{llr}
\text { Two years: } & 0.5(\mathrm{a}+\mathrm{b})= & 1.5 \text { years: } 0.4(\mathrm{a}+\mathrm{b})= \\
& \mathrm{y} \text { days } & \mathrm{y} \text { days } \\
\text { One year: } & 0.3(\mathrm{a}+\mathrm{b})= & \\
& \mathrm{y} \text { days } &
\end{array}
$$

Note 2: All days have been rounded. 